\title{
Children of the Golden Minster: St. Oswald's Priory and the Impact of Industrialisation on Child Health
}

\author{
Mary E. Lewis \\ Department of Archaeology, University of Reading, Reading RG6 6AB, UK \\ Correspondence should be addressed to Mary E. Lewis; m.e.lewis@reading.ac.uk
}

Received 28 February 2013; Revised 1 May 2013; Accepted 13 May 2013

Academic Editor: Maryna Steyn

Copyright (C) 2013 Mary E. Lewis. This is an open access article distributed under the Creative Commons Attribution License, which permits unrestricted use, distribution, and reproduction in any medium, provided the original work is properly cited.

\begin{abstract}
This study explores the disease experience of children buried within the cemetery of St. Oswald's Priory, Gloucester from AD1153 to 1857. Evidence for ages-at-death, infant mortality, and the prevalence of stress indicators, trauma, and pathology were compared between the early and postmedieval periods. The skeletal remains of these children provide evidence for child health spanning the economic expansion of Gloucester at St. Oswald's, from a mostly rural parish to a graveyard catering for families from the poorer northern part of the town and the workhouse. Results showed that the children from the postmedieval period in Gloucester suffered higher rates of dental caries (38\%) and congenital conditions (17.3\%) than their counterparts from the early and later medieval period. This paper serves to highlight the value of nonadult skeletal material in the interpretation of past human health in transitional societies and illustrates the wide variety of pathological conditions that can be observed in nonadult skeletons.
\end{abstract}

\section{Introduction}

The importance of studying nonadult skeletal remains from the archaeological context is gaining increasing recognition [1-3], but studies that focus solely on the diseases experience of children from past populations is still uncommon. Due to their rapid growth, children's bodies react swiftly to environmental insults making nonadult palaeopathology a useful measure in our understanding of transitional populations. This paper explores the health of 137 medieval children buried at St. Oswald's Priory, Gloucester between AD 1155 and 1857 [4]. Results of the skeletal analysis were originally presented by Rogers [5], but the palaeopathology of the children received little attention.

St. Oswald's parish extended over a large geographical area and those buried at the cemetery would have originally come from a number of outlying villages $[5,6]$. Between the 1100 and 1500s the majority of the people buried at St. Oswald's were living a rural lifestyle of subsistence agriculture, with children being employed in tending animals, lambing, and spinning wool $[7,8]$. Tenant farmers rented their properties from a Lord and were allocated strips of land which they harvested. Tenants were also provided with common grazing land for their livestock and shared access to the surrounding meadows and woodland [9]. Gloucester itself was a middle-ranking market town that benefited from its position as an inland port situated along the River Severn $[10,11]$. It received both raw and surplus goods for redistribution, and luxury items that were sold to the wealthy. Most people in the town were employed in manufacturing these raw items into goods to be sold. Iron, copper, and lead items were widely produced [12]. The rural communities that made up St. Oswald's extramural population would have had close links with Gloucester through the town's market which they would have visited regularly in order to sell livestock, grain, and raw materials for craftsmen $[8,12]$.

In 1563, the parish of St. Oswald's was relatively small and made up of 102 households. By 1743 this had only risen to 119 households with around 406 parishioners. But in the late 1700s, Gloucester experienced rapid economic expansion due to the growth of its various industries and manufacturing trades which attracted vast numbers of young migrants from the surrounding countryside [13]. By 1850 , shortly before the closure of the cemetery, the community of St. Oswald's had increased to around 2000 parishioners $[11,14]$ and the Parish Register of Baptisms and Burials suggests that the largest proportion of individuals buried at St. Oswald's were now living within the town. 
This dramatic population increase led to overcrowding, with the intensive development of existing streets forcing expansion into the suburbs and surrounding villages [13]. The crowded conditions led to problems with sanitation and waste disposal and frequent epidemics wiped out large sections of the community [13]. Population growth in the 16th and 17 th centuries was dependent on rural-urban migration. The influx of migrants only served to swell the numbers of poor unskilled labourers who had difficulty finding employment. In the records spanning AD 1595-1640, 69\% of apprentices came from the countryside outside the city [15]. Poor harvests in the 1580s and the 1640s led to fluctuations in food prices and many people, especially the urban poor, had difficultly affording basic items, despite the provision of subsidised food stocks from the town council. Tax records show that $58 \%$ of households in St. Oswald's parish (now renamed St Catherine's) were exempt from paying tax on account of poverty [15]. In the 17th century, attempts were made to improve living conditions within the town, including banning butchers from dumping offal into gutters and the River Severn [16]. Nevertheless in 1832, when a board of health was set up to deal with a cholera epidemic, they found the water systems and wells contaminated by cesspits and commented that the streets were "generally squalid" [17].

Apprentice records dating from the 1660 s show that Gloucester's two main industries were metalworking and clothing, with pin-making employing the greatest number of men, women, and children [15]. In 1626, Gloucester council charged John Tylsley with the task of setting up a pin-making business to employ the disabled children of the town $[11,13]$. By the 17 th century, individuals buried at St. Oswald's would have been employed in one of the town's manufacturing industries and probably represent the poorest sections of the community [4]. Listed occupations included a cordwainer, labourer, pin-maker, soap-boiler, servant, gardener, yeoman, blacksmith, brewer, hawker, bootmaker, baker, basket-maker, stone mason, tanner, and "the infant daughter of Abraham Rudnell," the bell-maker. From the ten examples where the ages were recorded on the stone monuments, the average age of death of the population was calculated to be 58 years [4]. Records show that a workhouse was established in Gloucester in 1701, catering for parishes including St. Catherine's, [18] and a recent review of the Parish Records shows that several of the individuals buried in the cemetery came from the workhouse (Watts pers. comm.).

The use of the cemetery at St. Oswald's spans this transition from a predominantly rural burial area to a parish catering for the poorer sections of the urban community. This paper explores the impact the social and economic changes had on the health of children living in the town, that saw Gloucester transform from a mostly rural later medieval centre to a hub of postmedieval industry and trade.

\section{Materials and Methods}

St. Oswald's Priory is situated to the northwest of Gloucester, near the city walls. In the early medieval period it was one of three major religious houses in the town, including the adjacent St. Peter's Abbey and Llanthony Secunda Priory [12].
Founded in AD 679 the "new minster" had Royal connections and was lavishly decorated, referred to as "golden" due to the amount of gold contained within it $[14,19]$. In AD 909, the new minster was rededicated to St. Oswald, whose relics were transferred (or translated) to the site [14]. By the 11th century, St. Oswald's parish had become a poor church, loosing much of its status as neighbouring St Peter's Abbey expanded [19]. By AD 1462, St. Oswald's was considered one of the poorest parishes in Gloucester. The Priory was eventually pulled down in $\mathrm{AD} 1656$, but the cemetery remained in use until AD 1857 [4].

The total sample comprised 600 burials dating from the Roman to the postmedieval period, excavated between 1975-8 and 1983. Of these, 28 were reburied during a much earlier excavation, and 508 are now held at the University of Reading. This study focuses on the 137 nonadults (defined as those 17 years and under), dating from the Anglo-Saxon to postmedieval periods. In the original report the skeletal sample was divided into four periods: Anglo-Saxon, here termed early medieval (AD 900-1120); Norman (AD 11201230); later medieval (AD 1230-1540) and postmedieval (AD 1540-1857). Individuals dating from the later medieval period were defined as being buried within the Priory itself and are assumed to have been the most wealthy individuals. For ease of analysis, the Norman and later medieval groups were merged to comprise individuals buried between AD 1120 and 1540 ( $n=87$ or $55.4 \%)$.

One early medieval child, aged around 1.5 years, was contained within a charcoal burial (B113) suggesting a high status, and eight children were located within the church, probably representing children of wealthy parishioners (B170, 171, 370, 384, 398, 403b, 349, and 155). They were all aged between 18 months and 9 years. In addition, five later medieval babies (11-12th century) were found in a single grave along the outer north wall of the nave [14].

Age at death estimates were obtained using standards of development for the deciduous and permanent dentition published by Moorrees et al. [20, 21] and tabulated by Smith [22]. When no teeth were present, diaphyseal lengths and skeletal maturation were used to assign age [23]. Perinates were aged using British standards developed by Scheuer et al. [24] based on diaphyseal lengths, or assigned a general age (early or late perinate) using the dimensions of the pars basilaris [25] and the development of the tympanic ring [26]. The skeletons were then divided into seven age categories, with individuals in the oldest age category (14.6-17.0 years) estimated to be older than 17.0 years when the root of the third molar was complete $(\mathrm{Rc}=16.9)$ but the apex open [21]. These biological ages are a useful tool for examining key stages of development in a child's life (i.e., at birth, during infancy, early and late childhood and adolescence) and provide a baseline from which nonadult populations from different societies can be compared. They are not meant to reflect the cultural concepts of age that existed in the medieval period, where individuals as old as 25 years were still considered "children" if they were employed as apprentices [27].

A general assessment of health is usually made by assessing the prevalence of "stress" indicators of the bones and teeth that provide evidence for chronic physiological stress, 
such as poor nutrition and infections, during childhood [3] and comparing the growth of children at different ages compared to modern standards. The prevalence of dental diseases (caries, abscesses, and antemortem tooth loss) on the deciduous and permanent teeth provides information on diet, oral hygiene, and more general health in children. Mean diaphyseal lengths were plotted against dental age estimates to produce skeletal growth profiles. Individuals aged using long bone lengths only were omitted from this part of the analysis. The lower limbs are considered to be the most sensitive to environmental stress as the femur and tibia are some of the fastest growing bones of the body [28]. Therefore, femoral diaphyseal length measurements were chosen to assess growth.

The term "cribra orbitalia" refers to pitted lesions on the orbital roofs. Although traditionally considered to be indicative of iron deficiency anaemia [29], the exact aetiology of cribra orbitalia is still open to question, and recently it has been suggested that the marrow expansion typical of these lesions is the result of megaloblastic anaemia due to vitamin $\mathrm{B}_{12}$ deficiency found in fresh meat and vegetables [30]. Iron deficiency anaemia, caused by chronic low grade infections, has also been associated with these lesions, that result from thinning of the cortical bone covering the orbital roof and expansion of the inner bone marrow [29]. This process can only occur during childhood when this area contains red bone marrow. Dental enamel hypoplasia present as linear and pitted defects on the surface enamel and are known to result from severe periods of stress that affect enamel production [31]. All dental crowns develop during childhood (c. 0-16 years) providing an almost permanent record of childhood stress. New bone formation (or periostitis) on the skeleton, as a result of inflammation of the soft tissues during an infection or resulting from mild trauma, is commonly recorded in bioarchaeology. The location of these lesions provides clues as to the cause of the condition. For example, new bone formation on the internal surface of the ribs signals a respiratory infection $[29,32]$, whereas new bone forming on the tibiae (shins) is often the result of inflammation due to a knock. Widespread new bone formation usually signals a more systemic disease (i.e., leprosy, syphilis, tuberculosis, or Caffey's disease).

The frequency of cribra orbitalia, dental enamel hypoplasia, and new bone formation was recorded in the St. Oswald's nonadults. Chi-squared tests for $2 \times 2$ and $2 \times c$ tables, with Yate's continuity correction [33], were carried out to test the differences in prevalence of stress indicators between the three periods. Cribra orbitalia was graded using the scheme devised by Stuart-Macadam [34] and an assessment of active and remodelled lesions was also recorded, using the descriptions provided by Mensforth et al. [35]. In order to ensure that nonspecific dental enamel hypoplasias were recorded, as opposed to those caused by localized trauma or infection, more than two teeth, on opposite sides of the jaw, had to be affected before "presence" was recorded. Enamel hypoplasias were only considered "absent" when four or more anterior teeth were available for examination and did not display defects. Healed (lamellar form) and active (fibre bone form) periostitis was recorded throughout the skeleton [29]
TABLE 1: Proportion of the nonadults to adults in the study sample.

\begin{tabular}{lcccc}
\hline Period & Adults & Nonadults & Total & $\%$ nonadults \\
\hline Early medieval & 117 & 22 & 139 & 15.8 \\
Later medieval & 144 & 87 & 231 & 37.6 \\
Postmedieval & 94 & 28 & 122 & 22.9 \\
\hline Total & 355 & 137 & 492 & 27.8 \\
\hline
\end{tabular}

TABLE 2: Demographic profile of the nonadults divided into periods.

\begin{tabular}{lcccc}
\hline $\begin{array}{l}\text { Age } \\
\text { (years) }\end{array}$ & $\begin{array}{c}\text { Early } \\
\text { medieval }\end{array}$ & $\begin{array}{c}{ }^{*} \text { Later } \\
\text { medieval }\end{array}$ & Post-medieval & Total \\
\hline Perinate & 3 & 19 & 1 & 23 \\
$0.0-0.5$ & 1 & 8 & 2 & 11 \\
$0.6-1.0$ & 0 & 5 & 0 & 5 \\
$1.1-2.5$ & 5 & $11(10+1)$ & 3 & 19 \\
$2.6-6.5$ & 8 & $18(15+3)$ & 11 & 37 \\
$6.6-10.5$ & 1 & $14(10+4)$ & 4 & 19 \\
$10.6-14.5$ & 3 & 4 & 7 & 14 \\
$14.6-17.0$ & 1 & 2 & 0 & 3 \\
?age & 0 & 6 & 0 & 6 \\
\hline Total & 22 & 87 & 28 & 137 \\
\hline
\end{tabular}

*(Numbers in brackets show number of "Norman" plus "later-medieval" skeletons).

and a lesion was considered "absent" when the tibiae were available for examination but none of the bones showed any infection. Finally, diseases of the metabolism (i.e., rickets and scurvy) were diagnosed using the criteria set out by Ortner and various colleagues [36-38], and Brickley and Ives [39]. Other pathologies, including dental disease, were recorded using standard published criteria $[29,40]$.

\section{Results and Discussion}

Table 1 presents the age-at-death distribution of the entire sample. At St. Oswald's Priory, $27.8 \%$ of the whole sample was made up of children less than 17 years of age. However, this is not consistent throughout the periods, with the majority of children $(n=87,63.5 \%)$ coming from the later medieval (or rather Norman) context. When the ages and periods are broken down (Table 2; Figure 1), children aged between 2.66.5 years were the most numerous.

3.1. Infant Mortality. Full-term infants are recognised as those aged between 38 and 40 weeks and in the past would have been viable without the aid of modern intervention. Clinically, infant mortality rates are subdivided into those who die before birth (late fetal or stillbirths), those dying at birth or within the first 27 days of extrauterine life (neonatal mortality), and those who die between 28 days and one year (postneonatal mortality). The majority of neonatal deaths are considered to reflect the endogenous state of the infant as the result of genetic and maternal influences (e.g., congenital anomalies, prematurity, low birth weight, and birth trauma), and post-neonatal mortality is seen more as 


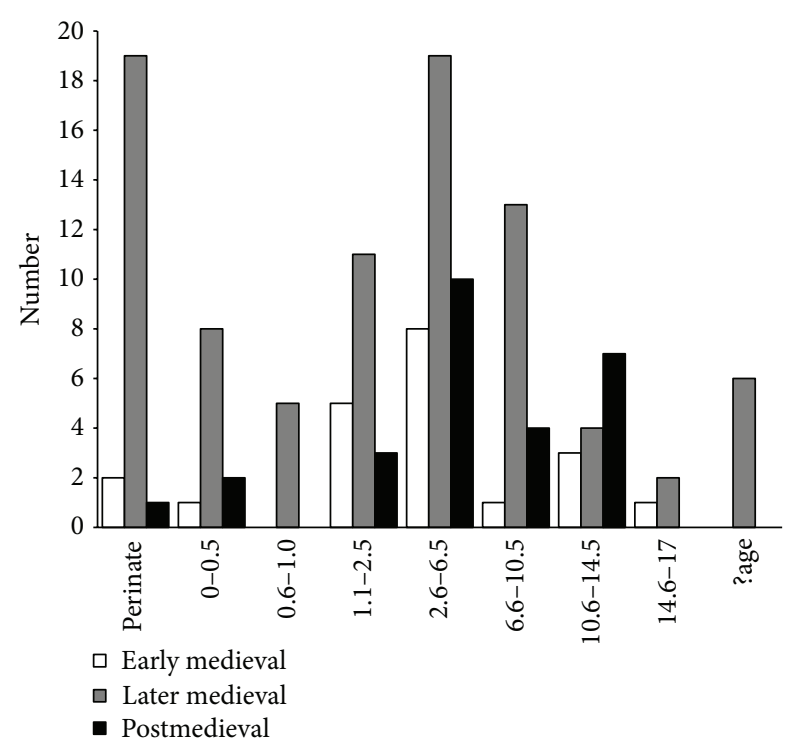

FIGURE 1: Number of nonadults by age and period.

a consequence of the child's external environment or exogenous factors (infectious diseases, poor nutrition, poisonings, and accidents) [41]. However, a crude estimate of exogenous and endogenous deaths can be established by looking at the numbers of individuals dying between the ages of c. 28 and 40 weeks of gestation compared to $41-48$ weeks. Hence, the percentage of neonatal deaths, including possible stillbirths and post-neonatal deaths, were compared between time periods to see if different patterns of infant mortality could be discerned.

In total, 22 individuals from the site were classed as neonates, with ages ranging from just 26 weeks to 40 weeks. The majority of neonates ( $n=8$ or $36 \%$ ) were aged at 39 weeks. There was only one postmedieval neonate (39 weeks) in the sample, and no neonates were recovered from inside the church. The neonates from the "mass grave" (B421a-e) by the external wall of the nave were aged between 35 and 40 weeks and are therefore are likely to represent those who died from a variety of causes including prematurity and infection, rather than a single factor such as infanticide. Within the later-medieval sample, one neonate displayed a series of lesions that probably represented a fatal congenital syndrome where the notochord failed to regress. The child (B418) died aged 39 weeks, but it is impossible to tell if they were stillborn. The thorax revealed a number of cleft vertebrae and fused (bifid) ribs, probably signalling other soft tissue anomalies that would have made this congenital syndrome incompatible with life (Figure 2). There were nine postneonates (41-48 weeks) in the sample, with six or $67 \%$ derived from the later medieval group. When the proportion of neonates and postneonates was compared (Figure 3), the number of neonates, or individuals dying from endogenous causes, outweighed postneonates in the early and later medieval samples, significantly so for the later medieval group $\left(X^{2}=\right.$ $13.52, P=0.001$, 1d.f.). In the postmedieval period there were more perinates dying several weeks after birth, suggesting an

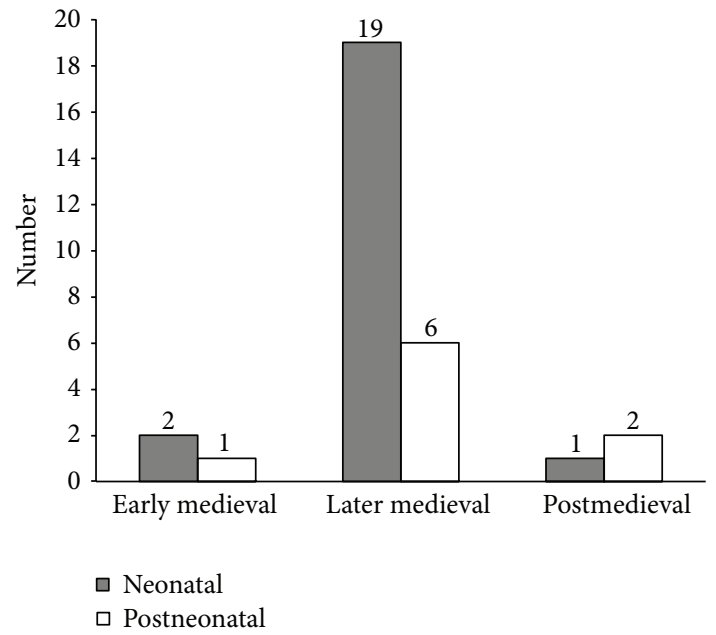

FIGURE 2: Number of perinates divided by gestational age (weeks) and period.

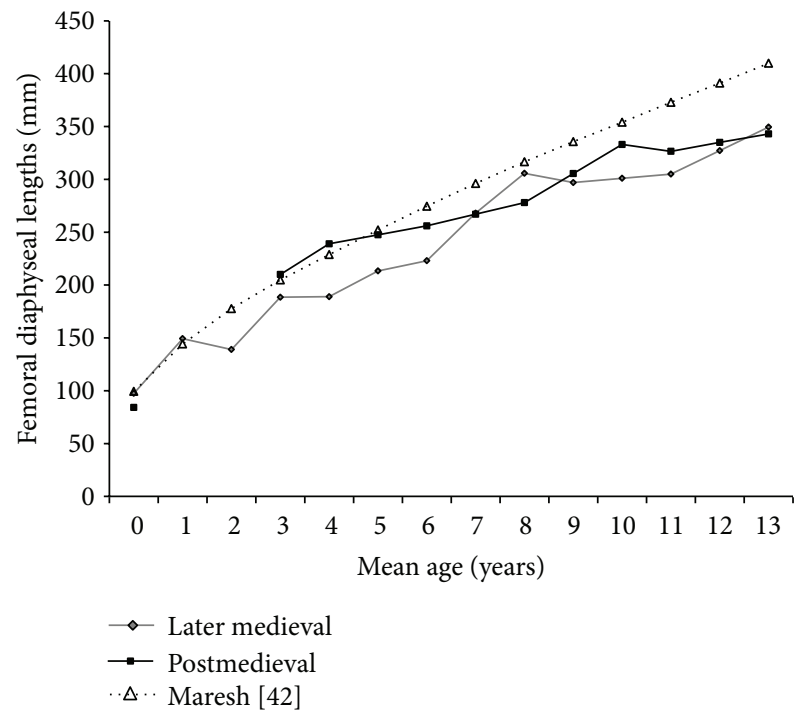

FIGURE 3: Growth profiles of the later and postmedieval children, compared to modern children.

environmental impact to their death. The numbers were too small to test for significance.

3.2. Growth Profiles. The growth profiles were plotted in one-year age categories. As there were only nine children in the early medieval sample with preserved femora, they were removed from the analysis between periods. The profiles for the later and postmedieval children were compared, with gaps in the data filled by taking an average of the measurement in the age group above and below it (Table 3 ). All data were then combined to provide a growth profile for the St. Oswald's children with individuals plotted and set against data from children in Denver between 1935 and 1955, provided by Maresh [42] (Figures 4 and 5). Despite the small sample sizes, the trend was for the heights of the children from St. Oswald's to fall below those of the modern children 
TABLE 3: Mean femoral diaphyseal lengths ( $\mathrm{mm}$ ). The numbers on italics are averaged from the measurements above and below them.

\begin{tabular}{lcccccc}
\hline $\begin{array}{l}\text { Mean age } \\
\text { (years) }\end{array}$ & \multicolumn{2}{c}{ Early medieval } & \multicolumn{2}{c}{ Later medieval } & \multicolumn{2}{c}{ Post-medieval } \\
\hline 0 & 1 & 83.98 & 5 & 97.51 & 1 & 84.2 \\
1 & 2 & 137.7 & 3 & 149.3 & 0 & \\
2 & 0 & & 1 & 139 & 0 & \\
3 & 0 & & 2 & 188.5 & 2 & 210 \\
4 & 2 & 208 & 2 & 189 & 1 & 239 \\
5 & 2 & 250 & 3 & 213.3 & 0 & 247.5 \\
6 & 0 & & 4 & 223 & 1 & 256 \\
7 & 0 & & 1 & 268 & 0 & 267 \\
8 & 1 & 291 & 5 & 305.7 & 1 & 278 \\
9 & 0 & & 1 & 297 & 0 & 305.5 \\
10 & 1 & 286 & 0 & 301 & 3 & 333 \\
11 & & & 1 & 305 & 2 & 326.5 \\
12 & & & 0 & 327.2 & 1 & 335 \\
13 & & & 1 & 349.5 & 2 & 343 \\
\hline Total & 9 & & 29 & & 14 & \\
\hline
\end{tabular}

after 2 years of age, but with the postmedieval children showing similar heights to the modern children between the ages of 3-5 years. Overall, the urban postmedieval children were taller than the rural children from the later medieval period, although limited numbers meant that this could not be tested statistically.

3.3. Dental Disease. Seventy-eight children had teeth available for examination; with 450 deciduous teeth (297 molars) and 660 permanent teeth ( 243 molars). Eleven children in total had dental caries (14.1\%), and three had developed dental abscesses. All of the children with abscesses came from the postmedieval period. The true prevalence rate (TPR) was $3.3 \%$ caries for deciduous dentition and $1.8 \%$ caries for the permanent teeth (Table 4). When examined by period, the postmedieval children had the highest rates of caries with a crude prevalence rate (CPR) of $38 \%$, followed by the early medieval group where $12.5 \%$ individuals had caries. The lowest rates were in the later medieval children with only $0.2 \%$ of teeth (TPR), or $2.4 \%$ individuals affected (CPR). This pattern of caries rates through time differs from previous research into dental disease in medieval children where reported rates for caries on deciduous teeth were at 3.5\%, $4.5 \%$, and $28.5 \%$ for early, later, and postmedieval children, respectively [43-45]. The drop in caries rates during the later medieval period is difficult to explain. James and Miller [46] found an overall caries rate of $9.1 \%$ for their later medieval children buried at Chuddington Church in London and other English later medieval sites showed much higher crude prevalence rates with 39\% for Blackfriars in Ipswich (Mays 1991), 34\% at Taunton, Sussex 16\% at Canterbury, Kent [47], and $17 \%$ at Wharram Percy, Yorkshire [48]. At just 14.1\%

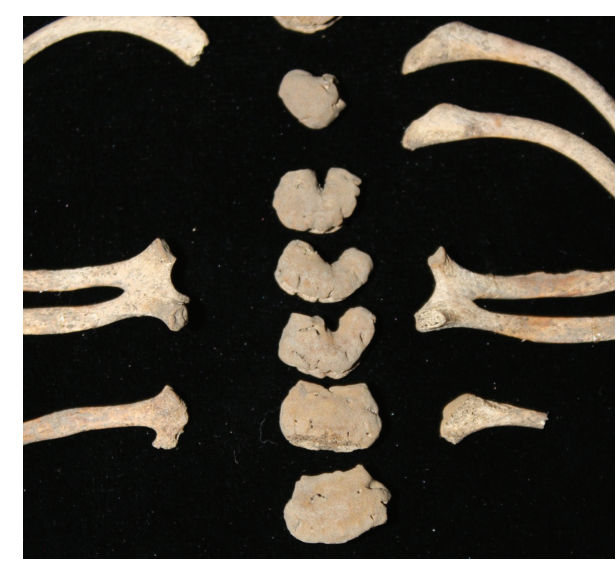

FIGURE 4: Skeleton B418 showing congenital fusion of the ribs and notochord regression failure.

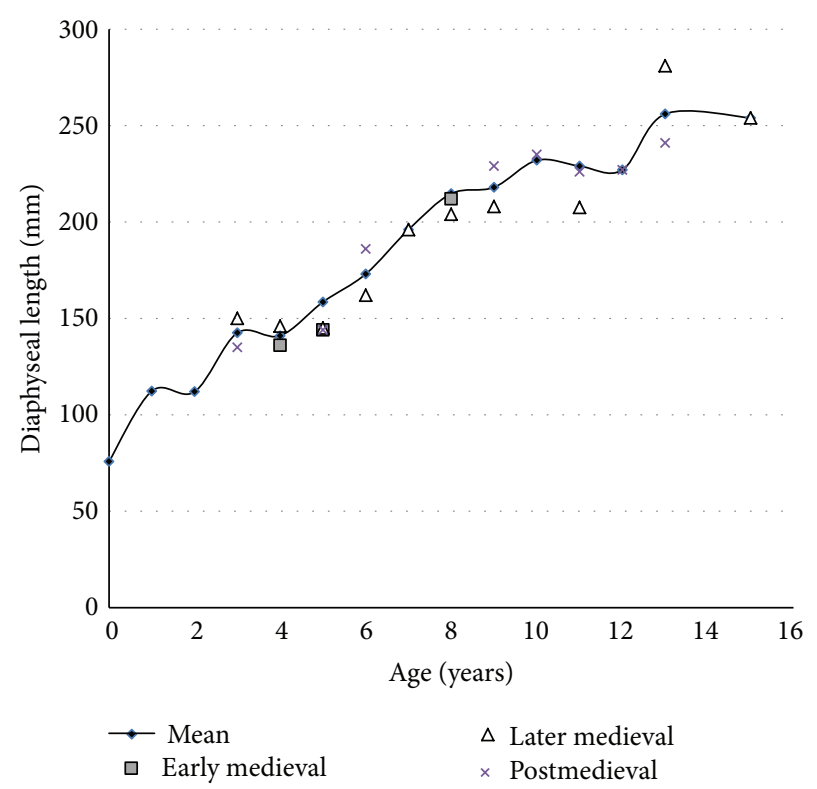

FIGURE 5: Growth profile of each individual against the mean, by period.

for all periods, the overall prevalence of dental caries at St. Oswald's Priory is low in comparison.

3.4. Cribra Orbitalia. Of the 77 nonadults with preserved orbits, 40 (52\%) children displayed cribra orbitalia; 25 (32\%) had cribra orbitalia graded 2, and 15 (19\%) had more severe cribra orbitalia at Grades 3 to 4 (Table 5, Figure 6), no cases were scored as severe as Grade 5, and Grade 1 was not considered pathological. The highest prevalence was in the later medieval sample where all cases were scored at Grade $3(n=2)$ and $4(n=2)$. Six of the seven cases of Grade 4 cribra orbitalia came from the later medieval group, with the final case from a postmedieval child. When then the early and later medieval (arguably "rural") samples were combined, $23 \%$ of the children with orbits had cribra orbitalia, compared 
TABLE 4: True percent prevalence of dental caries in the deciduous and permanent teeth.

\begin{tabular}{|c|c|c|c|c|c|c|}
\hline Period & Total teeth & $\begin{array}{c}\text { Deciduous } \\
\text { teeth/affected }\end{array}$ & $\begin{array}{c}\text { Deciduous } \\
\text { molars/affected }\end{array}$ & $\begin{array}{c}\text { Permanent } \\
\text { teeth/affected }\end{array}$ & $\begin{array}{c}\text { Permanent } \\
\text { molars/affected }\end{array}$ & $\%$ caries \\
\hline Early medieval & 207 & $132 / 4$ & $76 / 2$ & $75 / 0$ & $30 / 0$ & $1.9 \%$ \\
\hline Later medieval & 549 & $231 / 1$ & $162 / 0$ & $318 / 0$ & $114 / 0$ & $0.2 \%$ \\
\hline Post-medieval & 354 & $87 / 10$ & $59 / 9$ & $267 / 12$ & $99 / 11$ & $6.2 \%$ \\
\hline Total & 1110 & $450 / 15$ & $297 / 11$ & $660 / 12$ & $243 / 11$ & \\
\hline$\%$ caries & & $3.3 \%$ & $3.7 \%$ & $1.8 \%$ & $4.5 \%$ & \\
\hline
\end{tabular}

TABLE 5: Percent prevalence of cribra orbitalia.

\begin{tabular}{lccc}
\hline & $\begin{array}{c}\text { Early } \\
\text { medieval }\end{array}$ & $\begin{array}{c}\text { Later } \\
\text { medieval }\end{array}$ & Post-medieval \\
\hline$N$ affected/ $N$ with orbits & $2 / 10$ & $9 / 37$ & $4 / 16$ \\
$\%$ affected & 20 & 24.3 & 25 \\
\hline
\end{tabular}

TABLE 6: Crude prevalence rate of dental enamel hypoplasia.

\begin{tabular}{lccc}
\hline & $\begin{array}{c}\text { Early } \\
\text { medieval }\end{array}$ & $\begin{array}{c}\text { Later } \\
\text { medieval }\end{array}$ & Post-medieval \\
\hline Hypoplasia/ $N$ with teeth & $2 / 12$ & $15 / 40$ & $8 / 17$ \\
$\%$ affected & 16.6 & 37.5 & 47 \\
\hline
\end{tabular}

TABLE 7: Crude prevalence rate of endocranial lesions.

\begin{tabular}{lccc}
\hline & $\begin{array}{c}\text { Early } \\
\text { medieval }\end{array}$ & $\begin{array}{c}\text { Later } \\
\text { medieval }\end{array}$ & Post-medieval \\
\hline Lesions/ $N$ with crania & $0 / 14$ & $6 / 57$ & $0 / 20$ \\
$\%$ affected & 0 & 33.3 & 0 \\
\hline
\end{tabular}

to $25 \%$ of the postmedieval children. This difference was not significant $\left(X^{2}=0.02\right)$.

3.5. Dental Enamel Hypoplasia. Enamel hypoplasia was scored for presence or absence on individuals with at least four anterior teeth, including the canine. The type and number of teeth affected were not scored and so these figures represent crude rates only. Of the 69 children with anterior dentition, 25 (36\%) displayed enamel hypoplasia suggesting stress in early childhood (Table 6, Figure 6). The highest prevalence (47\%) came from the postmedieval sample, and $37.8 \%$ of the higher status later medieval children displayed enamel hypoplasia. When the early and later medieval groups were combined, $32.7 \%$ children had enamel defects, compared to $47 \%$ of the postmedieval children. This difference was significant $\left(X^{2}=6.65, P=0.01\right.$, 1.d.f. $)$.

3.6. Endocranial Lesions. These unusual lesions present as new bone formation on the internal or endocranial surface of the skull, of unknown aetiology [49], but they may be related to low grade inflammation of the meninges or conditions such as scurvy (vitamin $\mathrm{C}$ deficiency). As their aetiology is obscure, they are considered evidence for nonspecific physiological stress in the group. Of the 77 children with cranial fragments available for observation, six (7.8\%) had

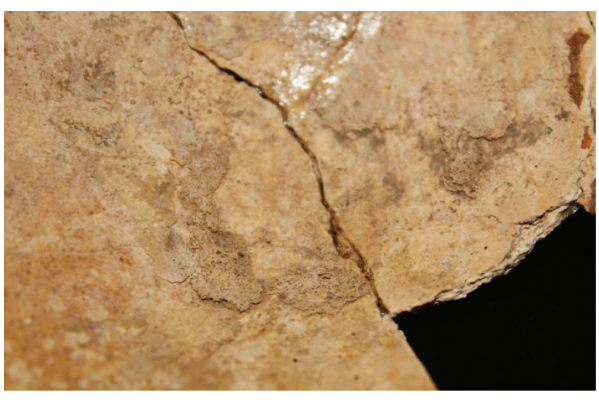

FIgURE 6: Fibre (woven) bone endocranial lesions on the parietal of a 3-4 year old later medieval child (B403b).

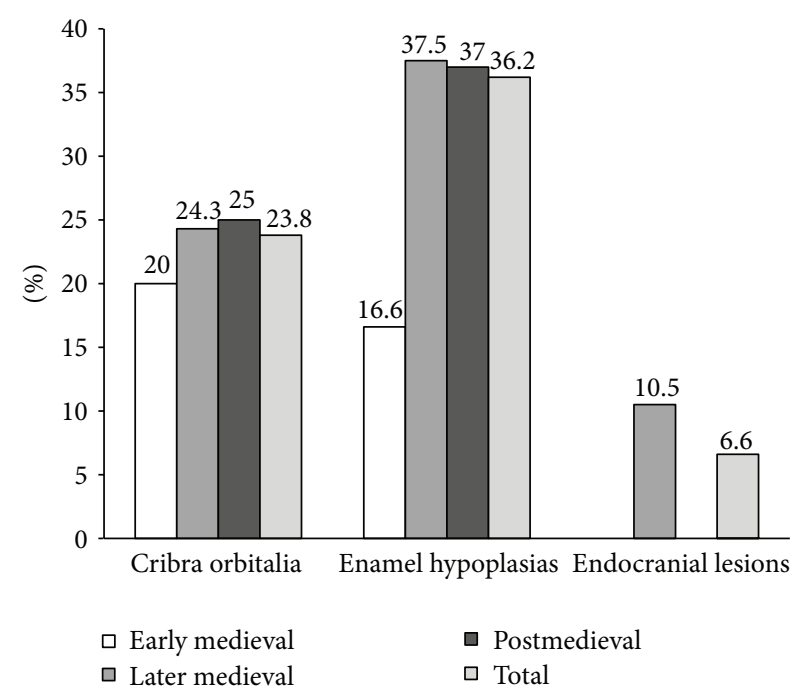

FIGURE 7: Crude percent prevalence of stress indicators, divided by period.

endocranial lesions in the form of active new bone formation (Figure 6). Table 7 (Figure 7) provides a breakdown of these cases. All of the cases came from children dating to the later medieval period, with the highest prevalence $(n=2 / 6$ or $33.3 \%$ ) in the high status group buried inside the Priory, and $10.5 \%$ affected overall.

3.7. General Skeletal Pathology. In the initial skeletal report [5] no pathologies were recorded on the nonadult remains (defined in 1999 as individuals between the ages of 0 15 years). Reanalysis of the material has revealed that of 
TABLE 8: Number of cases of skeletal trauma or pathology in the nonadult sample.

\begin{tabular}{|c|c|c|c|c|c|c|c|}
\hline Period & Naffected/N Individuals & Trauma & Infection & Congenital & Metabolic & Other & $\%$ affected \\
\hline Early medieval & $4 / 17$ & 1 & 1 & & & 2 & 23.5 \\
\hline Norman & $17 / 60$ & 2 & 4 & 4 & 5 & 3 & 28.3 \\
\hline Later medieval & $4 / 7$ & 3 & & & 1 & & 57.1 \\
\hline Post-medieval & $9 / 23$ & 1 & & 4 & & 6 & 39.1 \\
\hline Total & $37 / 107$ & 7 & 5 & 8 & 6 & 11 & 34.5 \\
\hline
\end{tabular}

the 107 children from St. Oswald's Priory with well-preserved skeletons to enable a pathological assessment, 37 (34.5\%) showed some form of skeletal pathology (Table 8). Overall, the rates of skeletal pathology, and in particular congenital conditions, were higher in the postmedieval sample (Figure 8). Although the results for overall pathology were not statistically significant for either the early medieval to later medieval transition $\left(X^{2}=0.40\right)$, or the postmedieval period $\left(X^{2}=0.73\right)$, the variety of lesions in this sample is worthy of note.

Three of the eight $(37.5 \%)$ high status children from the Nave of the church had head injuries: a blade injury (B403b, 3.5 years), a possible trepanation (B398, 8 years), and a depressed head injury (B171, 9 years). The most striking case of nonadult trauma was a fractured left humerus of an 18month-old child (B376) from the Norman period (Figure 9). This child was also notable as being the only one with clear signs of rickets (vitamin D deficiency) at the site, with frayed and expanded costal rib ends and pitting to the scapula. It is tempting to interpret this burial as one representing a child who was neglected and physically abused as shaft fractures of the humerus are rare in children [50]. However, the pathology may have other causes. In some cases children are born with a condition known as refractory rickets, where the child is unable to absorb vitamin D from their diet [51]. This in turn makes the bones weak and liable to fracture. Perhaps this child is an example of this congenital disorder, and the fracture occurred accidentally when the child was picked up. However, fractures as the result of rickets are more commonly found at the metaphyseal or growing end of the bone [52], and this fracture also displayed a fairly new callus, suggesting that the child sustained the fracture shortly before their death. Other evidence for metabolic disease at the site is less conclusive. Five children demonstrate lesions that may be interpreted as demonstrating either vitamin C (scurvy) or vitamin D (rickets) deficiency (B404, B97, B162, B398, and B104) and all date to the later medieval period. There are no cases of metabolic disease in the earlier or later periods.

There were several other cases of trauma in the sample. A 10-11-year-old early medieval child (B486) had a possible fracture to the fifth lumbar vertebra; a 6-month-old Norman child (B153) had a fractured clavicle that suggested a birth injury. Birth injury is also a likely explanation for the hypertrophy of the left distal humerus seen in a 42 week infant from the later medieval period (B15) (Figure 10. Verlinden pers. comm.). One 10-14-year-old child (B298) from the postmedieval period displayed a series of changes that may have been associated with trauma. The anterior

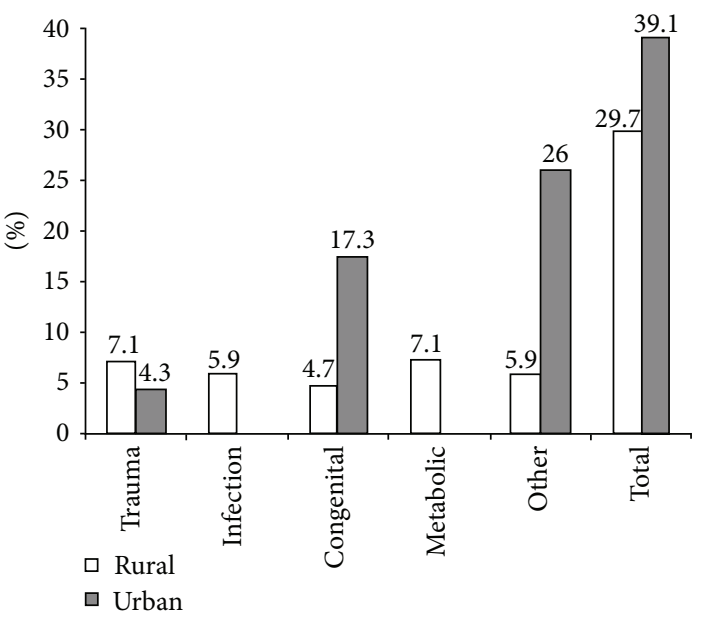

Figure 8: Percentage of pathologies in the rural (early and later medieval) and urban (postmedieval) children.

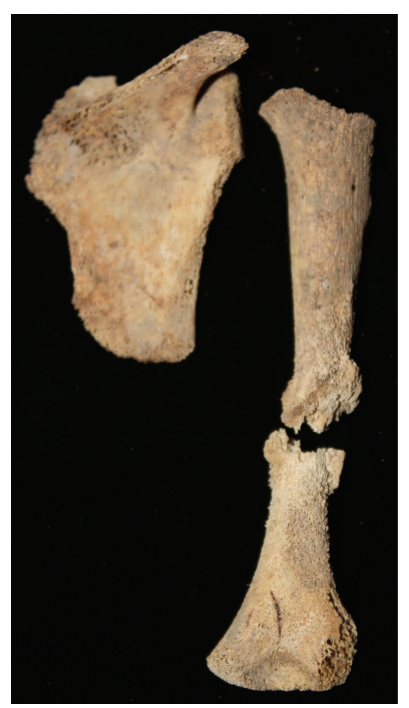

Figure 9: Left humerus and scapula of B376 note the pitting of the superior subscapular margin, indicative of rickets, and the newly formed callus at the humeral midshaft.

aspects of the lumbar vertebrae were compressed, and there was shortening of the left arm and leg compared to the right which may indicate damage to the nervous system. A congenital syndrome may also have caused these changes, as there was abnormal eruption of the dentition, with the lateral 


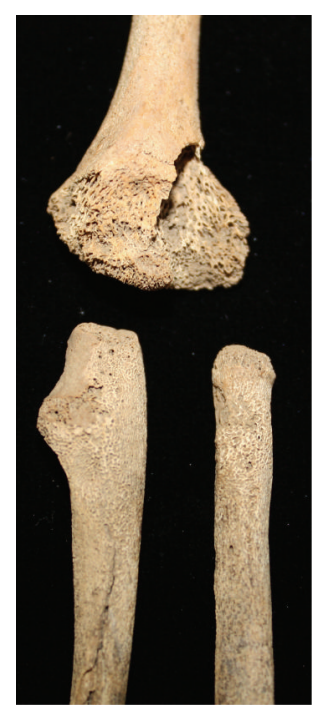

Figure 10: Probable spiral fracture of the distal humerus in B15.

maxillary incisor had failed to erupt, leaving the deciduous tooth in place, and the canine displayed delayed eruption. Two children had supercondylar processes of the humerus (one unilateral, one bilateral) and it is possible that they are the result of trauma (B 499, c.4 years; B107, c.7 years) as this is one of the most common areas for children to suffer trauma today [50]. A postmedieval child aged around 6 years (B251) had an exostosis on the right ulna that may be interpreted as a fracture, although these are all subtle and identifying trauma is a complex issue in children [53].

Several of the children had evidence for asymmetry of the limbs that may have resulted from an infection such as poliomyelitis or chickenpox which can cause temporary and permanent limb paralysis, or trauma at birth (Erb's palsy). Five cases of disuse atrophy were of the upper limb, in children aged between 5 and 15 years, and there were three cases of lower limb atrophy in children aged between 5 and 11 years. The most prominent cases were in B95 and B248 with $4 \mathrm{~cm}$ and $3.5 \mathrm{~cm}$ difference between the upper limbs, respectively, and B298 whose left leg was $3.5 \mathrm{~cm}$ shorter than the right. In most cases, the limbs were not significantly thinner, suggesting some mobility had returned to the affected limb before the child died. If all the children came from the same time period, this may indicate the troubling practices of a particular midwife operating in Gloucester, or perhaps the high incidence of breech births in the town. However, the cases were spread across time periods, with two early medieval, one later medieval, and five postmedieval cases. In most cases, the temporary paralysis caused by neural damage during a bout of polio is most likely, but two cases, both dating to the postmedieval period (AD1540-1857) are of more complex aetiology. B368, 2-6 years old, demonstrated severe wasting (thinning) of the left arm (Figure 11(a)), and a triangular rather than ovalshaped foramen magnum (Figure 11(b)) with evidence of basilar flattening was caused by the abnormal position of the first cervical vertebra (atlas). This condition usually results in neurological damage as the spinal cord is impinged and may have resulted in paralysis of the left arm. In addition to these changes, the child had premature suture closure to the side of the skull (occipito-mastoid suture) and possible hydrocephalus ("water-on-the-brain"), which suggests a possible but unspecified congenital syndrome in this child. The second case is of a 10-year-old child (B306), who demonstrated severe dental overcrowding, maleruption, and a supernumerary (Figure 12) and enlarge tooth (macrodont). Although there was postmortem damage to the anterior aspect of the maxilla, these changes are indicative of a cleft lip and palate which often accompanies a congenital syndrome. The child also demonstrated a cleft neural arch of the atlas that should fuse between 5 and 6 years of age [23]. In addition to the series of congenital defects already identified in the perinate B418, other congenital anomalies included a possible cervical rib (B163, 16 years), a possible cleft atlas (B42, 8 years), a reduced and narrow auditory meatus that may indicate the child was deaf or had defective hearing in one ear (B74, c.6 years), and cleft neural arches of the fifth lumbar vertebrae (B332, and B323 both c.10 years). It should be noted that congenital conditions are usually related to maternal stress or genetic mutations [54] and are equally distributed between the later and postmedieval periods.

There was one case of joint disease, an unusual occurrence in a nonadult sample. A 14-17 year adolescent from the later medieval (Norman) period demonstrated osteoarthritis in the left foot and right knee (patella), and osteochondritis dissecans a circulatory disorder, on the left distal humerus. All of these features indicate a high degree of physical activity at a young age, and it is tempting to suggest this individual was an apprentice. Finally, there were several cases of pathological changes that could not be assigned to a particular disease category; in particular, an infant (B430) showed honeycomb lesions of the metatarsals and vertebral spinous processes, that appeared pathological.

\section{Conclusions}

The paper examined the impact the transition from a predominantly rural lifestyle to an urban manufacturing environment had on the health of children from medieval Gloucester. A secondary aim was to highlight the variety of pathological lesions that can be identified on nonadult skeletal material. The St. Oswald's Priory sample comprised children dating from the early medieval period and contained both high and low status later medieval nonadults, who may have been working as apprentices in the metal or leather working industry, and postmedieval children, some of whom may have been living in the Gloucester Workhouse. In 1973, Weiss estimated that $30-70 \%$ of children in a developing society would die before the age of 15 years [54], with the highest mortality rates in the 1-5 year age group. This figure is often used as a "gold-standard" for measuring the completeness of a skeletal sample and the level of child representation. However, these data should be used with caution as they may not represent mortality rates of archaeological populations before industrialisation [55]. Infant mortality rates for many past populations are uncertain; however in 16th century England, 


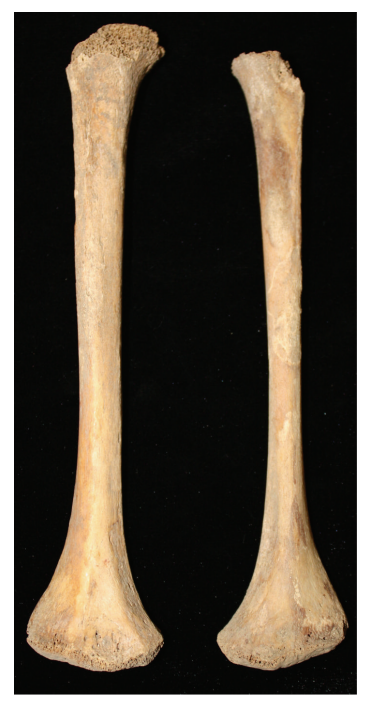

(a)

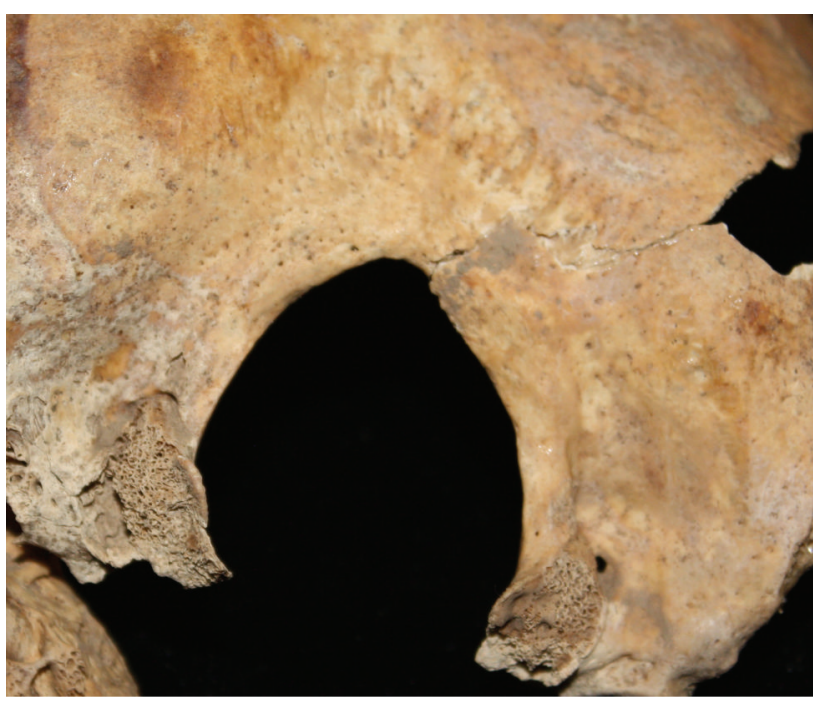

(b)

FIGURE 11: (a) Comparison on the left and right humerus of B368. Note the significant shortening and thinning of the left humeral shaft, indicative of disuse atrophy. (b) Triangular foramen magnum of B368. Note the flattening of the areas to the right of the formen magnum, signalling basilar compression, and neural impingement.

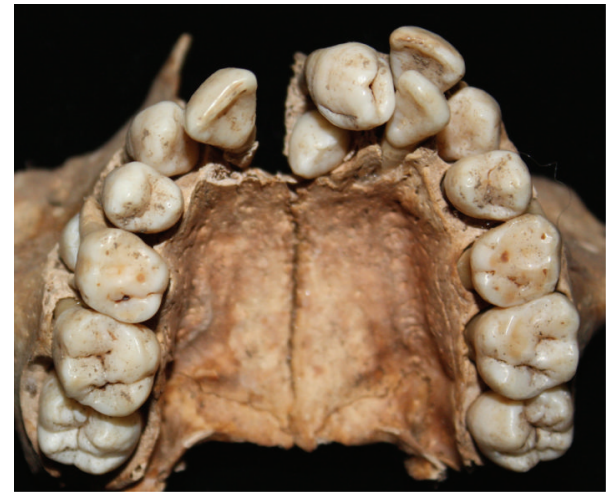

FIGURE 12: Unusual maxillary dentition of B306 showing a macrodontia supernumerary tooth at the midline. These features are seen in modern children with cleft lip and palate.

it was estimated that around $27 \%$ of children died before the age of one year [56]. Given the inconsistency with which stillbirths and neonatal deaths were reported in the past, historical records are likely to reflect a minimum number only [57]. At St. Oswald's Priory, only $27.8 \%$ of the whole sample was made up of children less than 17 years of age, suggesting that they are underrepresented. However, this is not consistent throughout the periods, with the majority of children (63.5\%) coming from the later medieval context. The infants (under 1-year) made up $28.4 \%$ of the nonadult sample but only three came from the latest period of the cemetery. A discrepancy between the burial registers and number of postmedieval infant skeletons recovered from the site led Rogers [5] to suggest that babies may have been buried in a special area of the cemetery which was not excavated. Additionally, in $\mathrm{AD} 1813-50$ the burial registers recorded that
$44 \%$ children died before the age of 5 years, but only $10 \%$ of postmedieval child burials were recovered from the excavated area [5].

The growth data for the children from the later and postmedieval contexts show that both fell below modern standards, a typical result for archaeological populations, but interestingly the postmedieval children seem to keep pace with the modern children between 3 and 5 years and at 11 years. Although the number is too small to draw any firm conclusions, this may indicate that the postmedieval urban group was receiving adequate nutrition when they died, suggesting that their deaths were the result of an acute infection, as opposed to general chronic malaise [58]. This result may also be interpreted as suggesting a high rate of mortality in this period that resulted in as many tall individuals entering the morality record as the short or stunted [59]. Other indicators of physiological stress suggested some adverse environmental effects on the postmedieval children. Enamel hypoplasias were significantly higher, and the majority of postmedieval perinates were aged over 40 weeks indicating factors relating to hygiene, diet, and exposure to infections caused their death. However, given that the postmedieval child sample is likely to be skewed, this should be treated with some caution. Dental caries rates, which were higher in the postmedieval group, can reflect general malnutrition in children if they occur as the result of occlusal enamel defects that are subsequently hidden $[60,61]$. The increased levels of dental caries and abscesses certainly suggest they had access to more refined foods such as sugar in their diet. What is evident is that there was a wide variety of congenital conditions in the postmedieval group, including cases of basilar compression, cleft palate and lip, and upper and lower limb atrophy. Such conditions often reflect maternal stress during pregnancy [54]. 
The higher status later-medieval group buried within the Priory building, although few, also interesting. Despite their potentially more privileged lifestyle, they had the most severe forms of cribra orbitalia, and highest rates of dental enamel hypoplasia and endocranial lesions. They were also the group with three potential head injuries.

In conclusion, its seems that the rapid population expansion and increased poverty highlighted in the documentary records for Gloucester during the postmedieval period is evident on the skeletal remains of the children from St. Oswald's Priory. This study illustrates the importance of careful examination of the nonadult material from archaeological sites in order to gain a detailed insight into population health in transitional societies in the past.

\section{Acknowledgments}

The author is grateful for the comments of the Editor and anonymous reviewers for their comments on an earlier version of this paper. The St. Oswald's Priory skeletal collection is held at the University of Reading, on long-term loan from Gloucester Museum, UK.

\section{References}

[1] J. Wileman, Hide and Seek. The Archaeology of Childhood, Tempus, Gloucestershire, UK, 2005.

[2] J. Baxter, The Archaeology of Childhood: Children, Gender and Material Culture, Altamira Press, Walnut Creek, Calif, USA, 2005.

[3] M. Lewis, The Bioarchaeology of Children. Perspectives From Biological and Forensic Anthropology, Cambridge University Press, Cambridge, UK, 2007.

[4] C. Heighway, Ed., The Golden Minster: the Anglo-Saxon Minster and Late Medieval Priory of St Oswald at Gloucester, Council for British Archaeology, Oxford, UK, 1999.

[5] J. Rogers, "Burials: the human skeletons," in The Golden Minster. The Anglo-Saxon Minster and Later Medieval Priory of St Oswald, Gloucester, C. Heighway and R. Bryant, Eds., vol. 117, pp. 229-246, Council for British Archaeology, York, UK, 1999.

[6] N. Baker and R. Holt, Urbanm Growth and the Medieval Church, Ashgate, Aldershot, UK, 2004.

[7] I. Whyte, "Britain from AD 500: landscape and townscape," in The Archaeology of Britain, J. Hunter and I. Ralston, Eds., pp. 348-367, Routledge, Abingdon, UK, 2009.

[8] N. Herbert, "Medieval Gloucester," in A History of Gloucestershire, C. Elrington, Ed., pp. 13-72, Alan Sutton Publishing, Gloucester, UK, 1988.

[9] C. Dyer, Standards of Living in the Later Middle Ages: Social Change in England c. 1200-1520, Cambridge University Press, Cambridge, UK, 1989.

[10] L. Fullbrook-Leggatt, "Medieval Gloucester I," Transactions of the Bristol and Gloucestershire Archaeological Society, vol. 66, pp. $1-48,1945$.

[11] P. Ripley, "The Economy of the City of Gloucester, 1660-1740," Transactions of the Bristol and Gloucestershire Archaeological Society, vol. 98, pp. 135-154, 1980.

[12] R. Holt, "Gloucester in the Century after the Black Death," Transactions of the Bristol and Gloucestershire Archaeological Society, vol. 103, pp. 149-161, 1985.
[13] N. Herbert, “Gloucester, 1720-1835," in A History of Gloucestershire, C. Elrington, Ed., pp. 124-169, Alan Sutton Publishing, Gloucester, UK, 1988.

[14] C. Heighway and M. Hare, "Gloucester and the Minster of St Oswald: a survey of the evidence," in The Golden Minster. The Anglo-Saxon Minster and Later Medieval Priory of St Oswald, Gloucester, C. Heighway and R. Bryant, Eds., vol. 117, pp. 1-46, Council for British Archaeology, York, UK, 1999.

[15] P. Clarke, "Early Modern Gloucester, 1547-1720," in A History of Gloucestershire, C. Elrington, Ed., pp. 73-123, Alan Sutton Publishing, Gloucester, UK, 1988.

[16] C. Heighway, The East and North Gates of Gloucester and Associated Sites. Excavation Monograph 4, Western Archaeological Trust, Bristol, UK, 1983.

[17] A. Juřica, “Gloucester, 1835-1985," in A History of Gloucestershire, C. Elrington, Ed., pp. 170-241, Alan Sutton Publishing, Gloucester, UK, 1988.

[18] S.S.f.t.P.o.C. Knowledge, An Account of Several Workhouses for Employment and Maintainance of the Poor, Joseph Downing, London, UK, 1725.

[19] R. Bryant and C. Heighway, "Excavations at the St Mary de Lode Church, Gloucester 1978-9," Transactions of the Bristol and Gloucestershire Archaeological Society, vol. 121, pp. 97-178, 2003.

[20] C. F. Moorrees, E. A. Fanning, and E. E. Hunt, "Formation and resorption of three deciduous teeth in children," American Journal of Physical Anthropology, vol. 21, pp. 205-213, 1963.

[21] C. F. Moorrees, E. A. Fanning, and E. E. Hunt, "Age variation of formation stages for ten permanent teeth," Journal of Dental Research, vol. 42, pp. 1490-1502, 1963.

[22] B. H. Smith, "Standards of human tooth formation and dental age assessment," in Advances in Dental Anthropology, M. A. Kelley and C. S. Larsen, Eds., pp. 143-168, Wiley-Liss, New York, NY, USA, 1991.

[23] L. Scheuer and S. Black, Developmental Juvenile Osteology, Academic Press, London, UK, 2000.

[24] J. L. Scheuer, J. H. Musgrave, and S. P. Evans, “The estimation of late fetal and perinatal age from limb bone length by linear and logarithmic regression," Annals of Human Biology, vol. 7, no. 3, pp. 257-265, 1980.

[25] L. Scheuer and S. Maclaughlin-Black, "Age estimation from the pars basilaris of the fetal and juvenile occipital bone," International Journal of Osteoarchaeology, vol. 4, pp. 377-380, 1994.

[26] D. S. Weaver, "Application of the likelihood ratio test to age estimation using the infant and child temporal bone," American Journal of Physical Anthropology, vol. 50, no. 2, pp. 263-270, 1979.

[27] B. Hanawalt, Growing Up in Medieval London, Oxford University Press, Oxford, UK, 1993.

[28] P. B. Eveleth and J. M. Tanner, Worldwide Variation in Human Growth, Cambridge University Press, Cambridge, UK, 2nd edition, 1990.

[29] D. Ortner, Identification of Pathological Conditions in Human Skeletal Remains, Academic Press, New York, NY, USA, 2nd edition, 2003.

[30] P. L. Walker, R. R. Bathurst, R. Richman, T. Gjerdrum, and V. A. Andrushko, "The causes of porotic hyperostosis and cribra orbitalia: a reappraisal of the iron-deficiency-anemia hypothesis," American Journal of Physical Anthropology, vol. 139, no. 2, pp. 109-125, 2009. 
[31] J. C. Rose, G. J. Armelagos, and J. W. Lallo, "Histological enamel indicator of childhood stress in prehistoric skeletal samples," American Journal of Physical Anthropology, vol. 49, no. 4, pp. 511-516, 1978.

[32] C. Roberts, D. Lucy, and K. Manchester, "Inflammatory lesions of ribs: an analysis of the Terry collection," American Journal of Physical Anthropology, vol. 95, no. 2, pp. 169-182, 1994.

[33] B. R. Kirkwood, Essentials of Medical Statistics, Blackwell Scientific Publications, London, UK, 1988.

[34] P. L. Stuart-Macadam, "Anemia in roman Britain: poundbury camp," in Health in Past Societies: Biocultural Interpretations of Human Skeletal Remains in Archaeological Contexts, H. Bush and M. Zvelebil, Eds., British Archaeological Research International Series, pp. 101-113, Oxford, UK, 1991.

[35] R. P. Mensforth, C. O. Lovejoy, J. W. Lallo, and G. J. Armelagos, "The role of constitutional factors, diet and infectious disease in the etiology of porotic hyperostosis and periosteal reactions in prehistoric infants and children," Medical Anthropology, vol. 2, no. 1, pp. 1-59, 1978.

[36] D. J. Ortner and M. F. Ericksen, "Bone changes in the human skull probably resulting from scurvy in infancy and childhood," International Journal of Osteoarchaeology, vol. 7, no. 3, pp. 212220, 1997.

[37] D. Ortner, E. Kimmerle, and M. Diez, "Probable evidence of scurvy in subadults from archaeological sites in Peru," American Journal of Physical Anthropology, vol. 108, pp. 321-331, 1999.

[38] D. J. Ortner and S. Mays, "Dry-bone manifestations of rickets in infancy and early childhood," International Journal of Osteoarchaeology, vol. 8, no. 1, pp. 45-55, 1998.

[39] M. Brickley and R. Ives, The Bioarchaeology of Metabolic Bone Disease, Academic Press, Oxford, UK, 2008.

[40] A. C. Aufderheide and C. Rodriguez-Martin, The Cambridge Encyclopedia of Human Paleopathology, Cambridge University Press, Cambridge, UK, 1998.

[41] S. Scott and C. J. Duncan, "Malnutrition, pregnancy, and infant mortality: a biometric model," Journal of Interdisciplinary History, vol. 30, no. 1, pp. 37-60, 1999.

[42] M. M. Maresh, "Linear growth of long bones of extremities from infancy through adolescence," American Journal of Diseases in Children, vol. 89, no. 3, pp. 725-742, 1955.

[43] W. J. Moore and E. Corbett, "The distribution of dental caries in ancient British populations. II. Iron Age, Romano-British and Mediaeval periods," Caries Research, vol. 7, no. 2, pp. 139-153, 1973.

[44] W. J. Moore and M. E. Corbett, "Distribution of dental caries in ancient British populations. III. The 17th century," Caries Research, vol. 9, no. 2, pp. 163-175, 1975.

[45] M. E. Corbett and W. J. Moore, "Distribution of dental caries in ancient British populations. IV. The 19th century," Caries Research, vol. 10, no. 6, pp. 401-414, 1976.

[46] P. M. James and W. A. Miller, "Dental conditions in a group of mediaeval English children," British Dental Journal, vol. 128, no. 8, pp. 391-396, 1970.

[47] H. Dawson, Unearthing Late Medieval Children: Heath, Status and Burial Practice in Southern England, Department of Archaeology and Anthropology, University of Bristol, 2011.

[48] S. Mays, "The human remains," in Wharram. A Study of a Settlement on the Yorkshire Wolds, XI: The Churchyard. York University Archaeological Publications 13, S. Mays, C. Harding, and C. Heighway, Eds., pp. 77-192, English Heritage, London, UK, 2007.
[49] M. E. Lewis, "Endocranial lesions in non-adult skeletons: understanding their aetiology," International Journal of Osteoarchaeology, vol. 14, no. 2, pp. 82-97, 2004.

[50] J. C. Y. Cheng, B. K. W. Ng, S. Y. Ying, and P. K. W. Lam, “A 10year study of the changes in the pattern and treatment of 6,493 fractures," Journal of Pediatric Orthopaedics, vol. 19, no. 3, pp. 344-350, 1999.

[51] V. Donghi, M. Di Frenna, A. di Lascio, G. Chiumello, and G. Weber, "Vitamin D dependent rickets, diagnostic and theraputic difficulties: two case reports," Journal of Pediatric Endocrinology and Metabolism, vol. 24, no. 9-10, pp. 801-805, 2011.

[52] T. D. Thacher, P. R. Fischer, J. M. Pettifor, J. O. Lawson, B. J. Manaster, and J. C. Reading, "Radiographic scoring method for the assessment of the severity of nutritional rickets," Journal of Tropical Pediatrics, vol. 46, no. 3, pp. 132-139, 2000.

[53] M. Lewis, "Sticks and Stones: exploring the nature and significance of child trauma in the past," in The Bioarchaeology of Human Conflict: "Traumatized Bodies" from Early Prehistory to the Present, C. Knüsel and M. Smith, Eds., Routledge, New York, NY, USA, 2013.

[54] K. Moore and T. Persaud, The Developing Human, Saunders, Philadelphia, Pa, USA, 8th edition, 2008.

[55] M. E. Lewis and R. Gowland, "Brief and precarious lives: infant mortality in contrasting sites from medieval and postmedieval England (AD 850-1859)," American Journal of Physical Anthropology, vol. 134, no. 1, pp. 117-129, 2007.

[56] N. Orme, Medieval Children, Yale University Press, New Haven, Conn, USA, 2001.

[57] J. C. Robertson, "Reckoning with London: interpreting the bills of mortality before John Graunt," Urban History, vol. 23, no. 3, pp. 325-350, 1996.

[58] S. R. Saunders and R. D. Hoppa, "Growth deficit in survivors and non-survivors: biological mortality bias in subadult skeletal samples," Yearbook of Physical Anthropology, vol. 36, pp. 127-151, 1993.

[59] J. W. Wood, G. R. Milner, H. C. Harpending et al., "The osteological paradox. problems of inferring prehistoric health from skeletal samples," Current Anthropology, vol. 33, no. 4, pp. 343-370, 1992.

[60] D. C. Cook and J. E. Buikstra, "Health and differential survival in prehistoric populations: prenatal dental defects," American Journal of Physical Anthropology, vol. 51, no. 4, pp. 649-664, 1979.

[61] E. A. O'Sullivan, S. A. Williams, and M. E. Curzon, "Dental caries in relation to nutritional stress in early English child populations," Pediatric Dentistry, vol. 14, no. 1, pp. 26-29, 1992. 

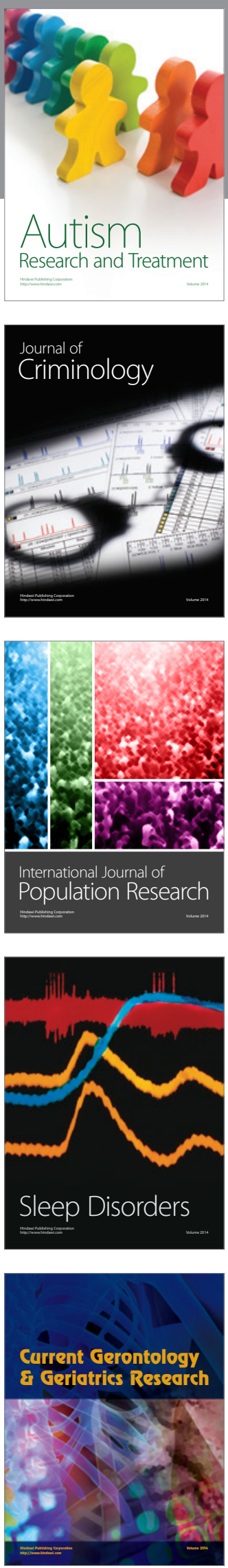
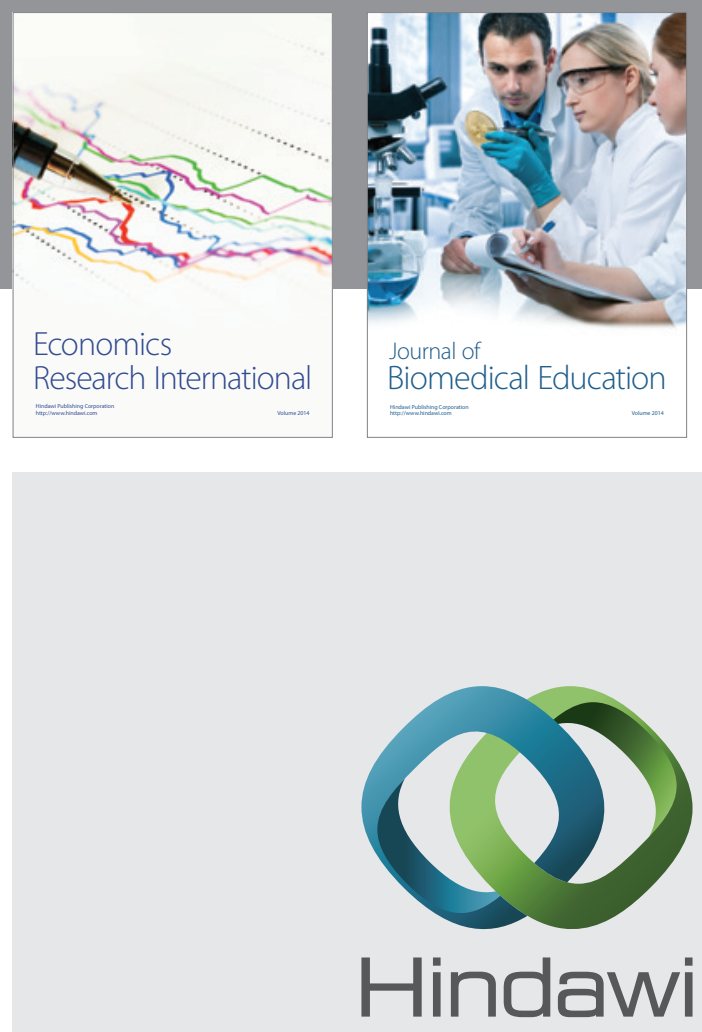

Submit your manuscripts at

http://www.hindawi.com
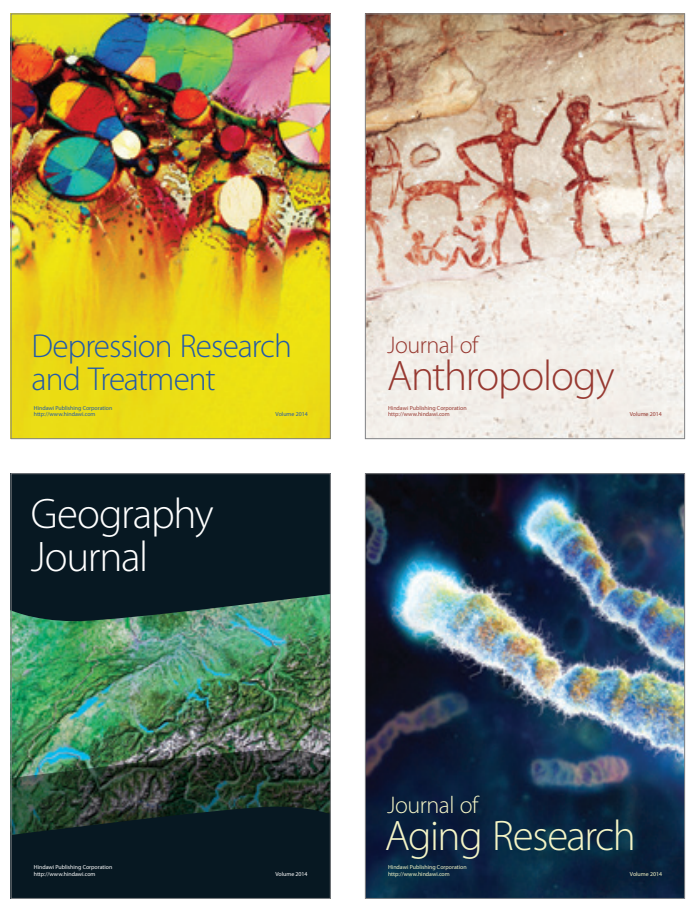
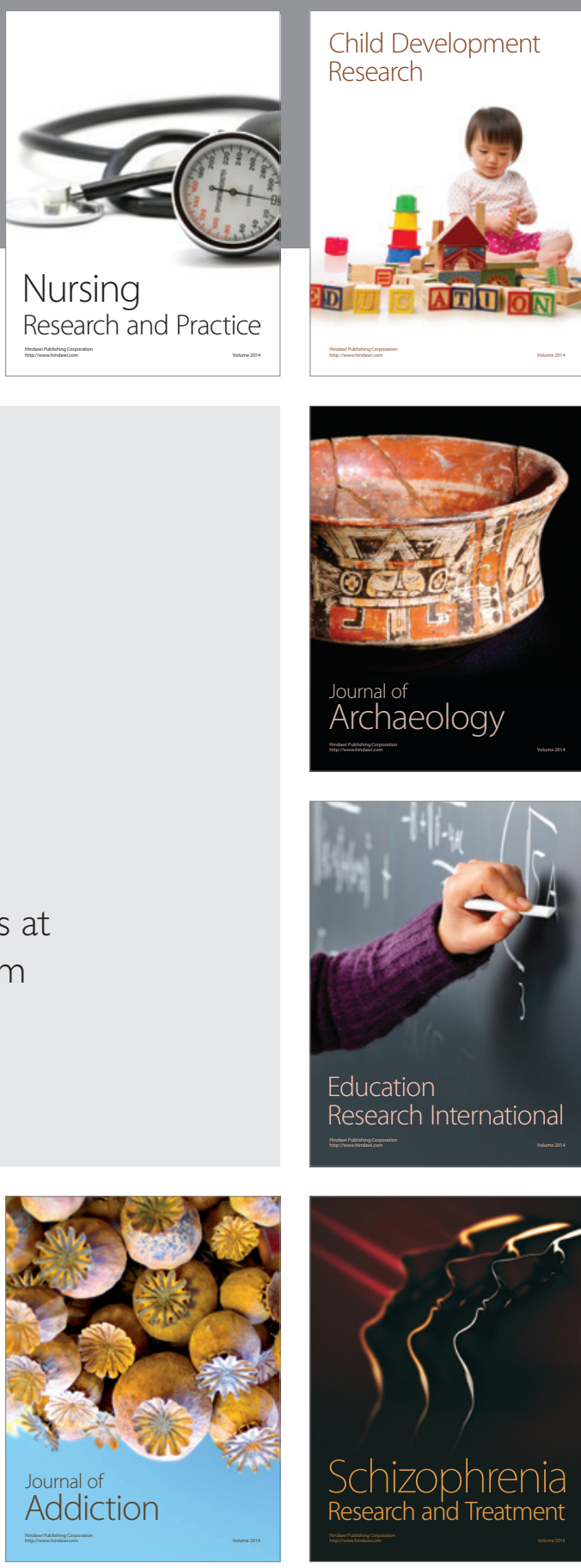

(D)
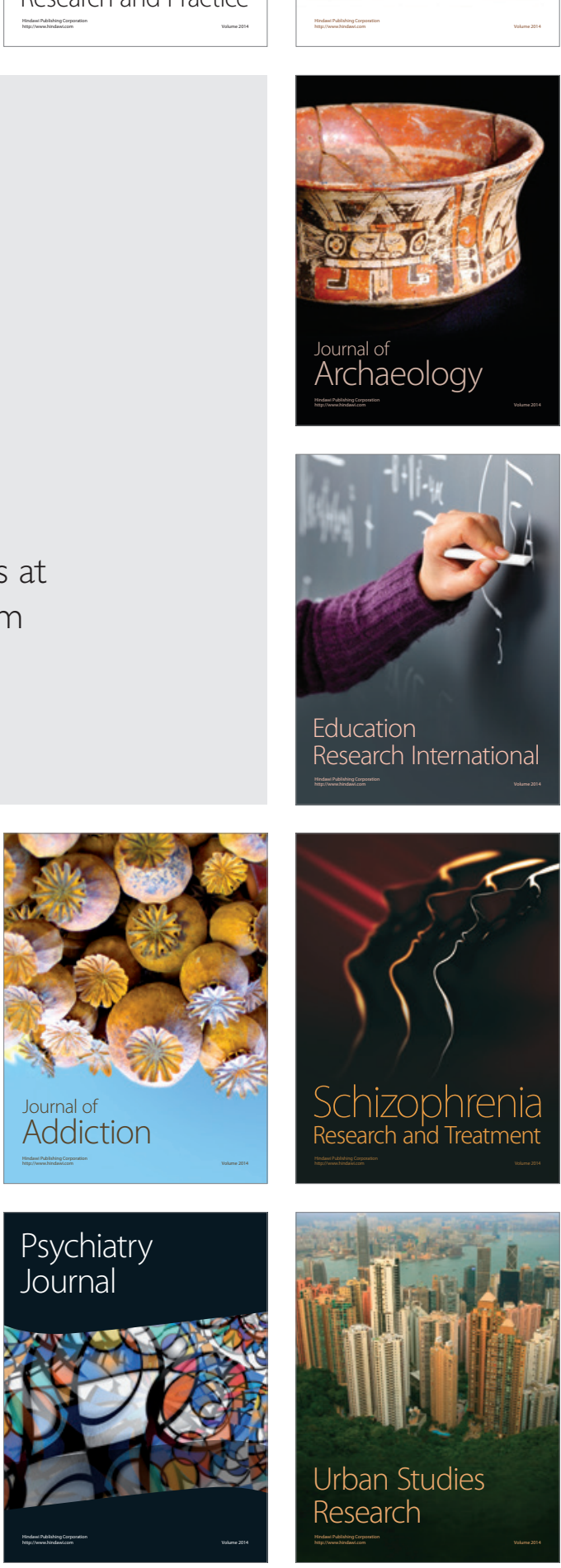